\title{
Faktor-Faktor Yang Mempengaruhi Kejadian Ketuban Pecah Dini (KPD) Pada Ibu Bersalin Di RS. Betha Medika
}

\author{
Ratna Zamilah, Nani Aisyiyah, Ari Waluyo \\ Fakultas IImu Kesehatan \\ Universitas Respati Indonesia \\ Jl. Bambu Apus 1 No.3 Cipayung Jakarta Timur 13890 \\ Email.nani@urindo.ac.id
}

\begin{abstract}
Abstrak
Ketuban pecah dini dapat meningkatkan infeksi dan infeksi merupakan salah satu penyebab langsung kematian ibu. Di RS. Betha Medika terjadi peningkatan kejadian ketuban pecah dini dari tahun 2016 mencapai 13,28\% kasus, sedangkan tahun 2017 mencapai 16,5\% kasus. Penelitian ini bertujuan untuk mengetahui faktor-faktor yang mempengaruhi kejadian ketuban pecah dini (KPD) pada ibu bersalin. Penelitian dengan pendekatan kuantitatif dengan rancangan penelitian case control. Jumlah populasi untuk kelompok kasus 74 ibu bersalin dengan KPD dan 74 kelompok kontrol. Analisis statistik menggunakan analisis univariat dan analisis bivariat. Variabel independen adalah umur, paritas, status pekerjaan dan kehamilan ganda. Sedangkan variabel dependen adalah ketuban pecah dini. Dari penelitian menunjukkan bahwa sebagian besar ibu bersalin mengalami ketuban pecah dini, memiliki usia yang berisiko, memiliki paritas yang banyak, dan ibu yang status pekerjaan nya bekerja. Hasil analisis bivariat menunjukkan bahwa ada pengaruh umur terhadap ketuban pecah dini dengan $p$ value 0,003 , ada pengaruh paritas terhadap ketuban pecah dini dengan $p$ value 0,001 dan ada pengaruh status pekerjaan terhadap ketuban pecah dini dengan $p$ value 0,004 . Terdapat pengaruh umur, paritas dan status pekerjaan terhadap kejadian ketuban pecah dini pada ibu bersalin. Dengan demikian diharapkan dapat dilakukan asuhan prakonsepsi dan deteksi dini faktor yang mempengaruhi ketuban pecah dini pada ibu hamil sangat penting untuk dilakukan dalam upaya pencegahan ketuban pecah dini.
\end{abstract}

Kata Kunci : Ketuban pecah dini, Umur, Paritas, Status Pekerjaan

Kepustakaan : 21 Buku, 5 Jurnal, 4 Situs (2001-2017)

\section{Abstract}

Premature rupture of membranes can increase infection and infection is one of the direct causes of maternal death. At the hospital. Betha Medika there was an increase in the incidence of premature rupture of membranes from 2016, reaching $13.28 \%$ of cases, while in 2017 it reached $16.5 \%$ of cases. This study aims to determine the factors that influence the incidence of premature rupture of membranes (PROM) in maternal. Research with a quantitative approach with a case control research design. The population for the case group was 74 mothers with PROM and 74 in the control group. Statistical analysis used univariate analysis and bivariate analysis. The independent variables are age, parity, employment status and multiple pregnancies. Meanwhile, the dependent variable is premature rupture of membranes. The research shows that most of the women who give birth experience premature rupture of membranes, have a risky age, have a lot of parity, and are mothers http://ejournal.urindo.ac.id/index.php/kesehatan

Article History : 
whose employment status is working. The results of the bivariate analysis showed that there was an effect of age on premature rupture of membranes with $p$ value of 0.003 , there was an effect of parity on premature rupture of membranes with $p$ value of 0.001 and there was an effect of work status on premature rupture of membranes with $p$ value of 0.004 . There is an effect of age, parity and work status on the incidence of premature rupture of membranes in mothers who give birth. Thus, it is hoped that preconception care can be carried out and early detection of factors that affect premature rupture of membranes in pregnant women is very important in an effort to prevent premature rupture of membranes.

Keywords: premature rupture of membranes, age, parity, work status

\section{A. LATAR BELAKANG}

Ukuran keberhasilan suatu pelayanan kesehatan tercermin dari penurunan angka kematian ibu (AKI) atau maternity mortality rate (MMR) sampai pada batas angka terendah yang dapat dicapai sesuai dengan kondisi dan situasi setempat serta waktu. AKI merupakan salah satu indicator untuk melihat derajat kesehatan perempuan serta merupakan salah satu target yang telah ditentukan dalam tujuan pembangunan millennium ke 5 yaitu meningkatkan kesehatan ibu dimana target yang akan dicapai sampai tahun 2015 adalah mengurangi sampai $3 / 4$ resiko jumlah kematian ibu. (Depkes RI 2010).

Kematian ibu atau kematian maternal adalah kematian seorang ibu sewaktu hamil atau dalam waktu 42 hari sesudah berakhir kehamilan, tidak bergantung pada tempat atau usia kehamilan. Kematian ibu dibagi menjadi kematian langsung dan tidak langsung, kematian ibu langsung adalah sebagai akibat komplikasi kehamilan, persalinan, atau masa nifas, dan segala intervensi atau penanganan tidak tepat dari komplikasi tersebut. Kematian ibu tidak langsung merupakan akibat dari penyakit yang sudah ada atau penyakit yang timbul sewaktu kehamilan yang berpengaruh terhadap kehamilan, misalnya malaria, anemia, HIV/AIDS dan penyakit kardiovaskuler. Sedangkan penyebab kematian bayi adalah asfiksia, trauma kelahiran, infeksi, prematuritas, kelainan bawaan, dll. (Prawirohardjo 2010).

Salah satu unsur kesejahteraan umum dari tujuan nasional adalah pembangunan kesehatan. Sasaran pembangunan kesehatan di Indonesia yang akan dicapai pada tahun 2025 adalah meningkatnya derajat kesehatan masyarakat yang setinggi-tingginya. (Depkes RI 2010).

World Health Organization (WHO) memperkirakan angka kematian ibu sebesar 500.000 jiwa dan angka kematian bayi sebesar 10 juta jiwa per tahun. 
Kejadian kematian ibu dan bayi sebagian besar terdapat di negara berkembang yaitu sebesar 98\%-99\% dimana kematian ibu dan bayi di negara berkembang 100\% lebih tinggi dibandingkan dengan negara maju. Angka Kematian Ibu (AKI) di Indonesia masih tinggi, bahkan jumlah perempuan Indonesia yang meninggal saat melahirkan mencapai rekor tertinggi di Asia. (www.aki dan akb.com diakses pada tanggal 23-032017).

Pembangunan kesehatan mendapat perhatian khusus dalam program Sustainable Development Goals (SDGs). SDGs yang merupakan kelanjutan dari program Millenium Development Goals (MDGs) memiliki salah satu target untuk menurunkan angka kematian ibu dan mengakhiri kematian bayi. Adapun targetnya yaitu mengurangi angka kematian ibu (AKI) hingga 70/100.000 kelahiran hidup (KH) dan menurunkan angka kematian bayi (AKB) hingga 12/1.000 KH pada tahun 2030. (Kementrian Kesehatan RI 2015).

Berdasarkan Survey Demografi Kesehatan Indonesia (SDKI) tahun 2012, angka kematian maternal di Indonesia mencapai 359/100.000 kelahiran hidup, itu berarti setiap 100.000 kelahiran hidup masih ada sekitar 359 ibu yang meninggal akibat komplikasi kehamilan dan persalinan. Penyebabnya karena perdarahan, PEB dan infeksi, infeksi pada ibu bersalin dapat disebabkan oleh Ketuban Pecah Dini (KPD).

Upaya-upaya yang bertujuan untuk menyelamatkan ibu dalam kaitannya dengan kehamilan sangat bervariasi di berbagai negara, tergantung sumber daya yang ada dan lingkungan sosial budaya setempat. Salah satu intervensi strategi upayanya yaitu upaya safe motherhood yang dinyatakan sebagai empat pilar safe motherhood, yaitu keluarga berencana, pelayanan antenatal, persalinan aman, dan pelayanan obstetric essensial dimana target yang ditetapkan untuk tahun 2015 untuk Indonesia yaitu menurunkan angka kematian ibu. (Hermiyanti, 2008).

Ketuban Pecah Dini (KPD) adalah pecahnya ketuban sebelum waktunya melahirkan/sebelum inpartu, pada pembukaan $<4 \mathrm{~cm}$ (fase laten). Hal ini dapat terjadi pada akhir kehamilan maupun jauh sebelum waktunya melahirkan. KPD preterm adalah KPD sebelum usia kehamilan 37 minggu. KPD yang memanjang adalah KPD yang terjadi lebih dari 12 jam sebelum waktunya melahirkan. (Nugroho 2012).

KPD merupakan komplikasi yang berhubungan dengan kehamilan kurang bulan, dan mempunyai kontribusi yang besar pada angka kematian perinatal pada bayi yang kurang bulan. Pengelolaan KPD 
pada kehamilan kurang dari 34 minggu sangat kompleks, bertujuan untuk menghilangkan kemungkinan terjadinya prematuritas dan Respiration Dystress Syndrome (RDS). (Nugroho 2012).

Penyebab dari KPD tidak atau masih belum diketahui secara jelas, maka usaha preventif tidak dapat dilakukan, kecuali dalam usaha menekan infeksi. Faktor yang berhubungan dengan meningkatnya insidensi KPD yaitu fisiologi selaput amnion, inkompetensi serviks, infeksi vagina/serviks,kehamilan ganda, polihidramnion, trauma, distensi uteri, stress maternal, stress fetal, infeksi, serviks yang pendek, serta prosedur medis. (Rahmawati 2011).

Komplikasi paling sering terjadi pada ketuban pecah dini sebelum usia kehamilan 37 minggu adalah sindrom distress pernafasan, yang terjadi pada 10$40 \%$ bayi baru lahir. Resiko infeksi meningkat pada kejadian ketuban pecah dini. Selain itu kejadian prolapse atau keluarnya tali pusat dapat terjadi pada ketuban pecah dini. (Ayurai 2010).

Kejadian ketuban pecah dini dapat menimbulkan beberapa masalah bagi ibu maupun janin, misalnya pada ibu dapat menyebabkan infeksi puerperalis/masa nifas, partus lama, dapat pula menimbulkan perdarahan postpartum, morbiditas dan mortalitas maternal bahkan kematian (Cuningham 2006).

Penatalaksanaan ketuban pecah dini tergantung pada umur kehamilan dan tanda infeksi intrauterine. Pada umumnya lebih baik untuk membawa semua pasien dengan ketuban pecah dini ke rumah sakit dan melahirkan bayi yang usia gestasinya >37 minggu dalam 24 jam dari pecahnya ketuban untuk memperkecil resiko infeksi intrauterine. (Winkjosastro 2006).

Berdasarkan data Puskesmas Balongsari Surabaya pada Register Persalinan Puskesmas Balongsari Surabaya, tahun 2010-2012 menunjukkan bahwa kejadian KPD cenderung mengalami peningkatan dari tahun 2010 sampai 2012. Dari tahun 2010 sampai 2011 terjadi peningkatan $7,1 \%$, sedangkan dari tahun 2011 sampai 2012 terjadi peningkatan 4,9\%. Jadi rerata kejadian KPD adalah $12 \%$. Hal ini relative lebih tinggi dari keadaan normal perempuan hamil aterm yang mengalami ketuban pecah dini menurut Saifudin, A.B (2010) yaitu 8-10\%.

Berdasarkan data yang diperoleh dari Dinas Kesehatan Kabupaten Sukabumi pada tahun 2016 AKI 54/100.000 kelahiran hidup disebabkan oleh 40,75\% karena eklamsi/Pre Eklamsi Berat (PEB)/Hipertensi Dalam Kehamilan (HDK), 33,4\% karena perdarahan, 7,5\% karena penyakit jantung, 
5,5\% karena sepsis, 3,71\% karena penyakit TB paru,dan 9,14\% karena penyebab lain.

Data Rekam Medis yang didapatkan pada tahun 2016 di RS. Betha Medika menunjukkan jumlah persalinan dengan ketuban pecah dini (KPD) yaitu sebanyak $13,28 \%$ kasus dari 557 persalinan, sedangkan pada tahun 2017 dari bulan Januari-Februari yaitu sebanyak 16,5\% kasus dari 115 persalinan. (Rekam Medis RSBM tahun 2016 dan 2017).

Berdasarkan uraian diatas maka penulis tertarik untuk melakukan penelitian tentang "Faktor-Faktor yang Mempengaruhi Kejadian Ketuban Pecah Dini (KPD) pada Ibu Bersalin di RS.Betha Medika Sukabumi Tahun 2016".

\section{B. Metode Penelitian}

\section{Pendekatan Penelitian}

Pendekatan penelitian ini menggunakan pendekatan kuantitatif, dengan dengan desain studi case control dengan pendekatan retrospektif. Desain studi case control dalam penelitian ini bertujuan untuk melihat hubungan antara variabel independen seperti usia ibu bersalin, paritas ibu bersalin, status pekerjaan ibu bersalin dan kehamilan ganda dengan variabel dependen yaitu kejadian Ketuban Pecah Dini (KPD).

\section{Tempat dan Waktu}

Penelitian ini dilaksanakan di RS. Betha Medika Sukabumi pada bulan JanuariApril 2017.

\section{Instrument Penelitian}

Alat ukur yang digunakan dalam penelitian ini adalah data rekam medis berupa status pasien ibu bersalin di RS. Betha Medika tahun 2016, dengan menggunakan checklist.

\section{Populasi dan Sampel Penelitian}

Populasi adalah wilayah generalisasi yang terdiri atas objek atau subjek yang mempunyai kualitas dan karakteristik tertentu yang ditetapkan oleh peneliti untuk dipelajari kemudian ditarik kesimpulannya. (Hidayat 2009)

Populasi dalam penelitian ini adalah seluruh ibu bersalin di RS. Betha Medika Sukabumi pada tahun 2016 dengan jumlah 557 persalinan.

Sampel adalah sebagian dari populasi yang diambil untuk diketahui karakteristik. Sampel adalah sebagian yang diambil dari keseluruhan objek yang diteliti dan dianggap mewakili seluruh populasi. (Sugiyono 2005)

Sampel dalam penelitian ini adalah sebagian Ibu Bersalin yang tercatat dalam register kamar bersalin Rumah Sakit Betha Medika tahun 2016. Dengan kasus yaitu seluruh ibu bersalin dengan Ketuban Pecah Dini (KPD) dan kelompok kontrol yaitu ibu 
bersalin yang tidak mengalami Ketuban Pecah Dini (KPD).

Teknik pengambilan sampel menggunakan 1:1 berdasarkan case dan kontrol yaitu 74 case (KPD), dan 74 kontrol (Non KPD) dengan menggunakan teknik random sampling.

\section{Teknik Pengumpulan Data}

Cara yang digunakan dalam penelitian ini adalah dengan menggunakan data sekunder yaitu data rekam medis berupa status pasien di RS. Betha Medika Tahun 2016.

\section{Analisis Data}

a. Analisis Univariat

Pada umumnya dalam analisis ini hanya menghasilkan distribusi frekuensi dan persentase dari setiap variabel. (Notoatmodjo 2010)

\section{b. Analisis Bivariat}

Analisis bivariat adalah analisa yang dilakukan oleh 2 variabel yang diduga berhubungan atau berkorelasi. (Notoatmodjo 2005)

\section{c. Odds Ratio}

Hasil uji Chi Square hanya dapat menyimpulkan ada tidaknya perbedaan proporsi antar kelompok atau dengan kata lain kita hanya dapat menyimpulkan ada atau tidaknya hubungan dua variabel kategorik.

\section{HASIL DAN PEMBAHASAN}

1. Hasil Analisis Univariat

Tabel 5.1

Distribusi Frekuensi Kejadian Ketuban

Pecah Dini (KPD) pada Ibu Bersalin di RS.

Betha Medika Sukabumi Tahun 2016

\begin{tabular}{ccc}
\hline $\begin{array}{c}\text { Ketuban Pecah } \\
\text { Dini (KPD) }\end{array}$ & Frekuensi & $\%$ \\
\hline Tidak KPD & 74 & 50 \\
KPD & 74 & 50 \\
\hline Jumlah & 148 & 100 \\
\hline
\end{tabular}

Tabel 5.2

Distribusi Frekuensi Umur Pada Ibu Bersalin

di RS. Betha Medika Sukabumi Tahun 2016

\begin{tabular}{ccc}
\hline Umur & Frekuensi & $\%$ \\
\hline Tidak Berisiko & 46 & 31,1 \\
Berisiko & 102 & 68,9 \\
\hline Jumlah & 148 & 100 \\
\hline
\end{tabular}

Tabel 5.3

Distribusi Frekuensi Jumlah Paritas Pada Ibu Bersalin

di RS. Betha Medika Sukabumi Tahun 2016

\begin{tabular}{ccc}
\hline Umur & Frekuensi & $\%$ \\
\hline $\begin{array}{c}\text { Primipara } \\
\text { Multipara dan }\end{array}$ & 50 & 33,8 \\
Grandemultipara & 98 & 66,2 \\
\hline Jumlah & 148 & 100 \\
\hline
\end{tabular}

Tabel 5.4

Distribusi Frekuensi Status Pekerjaan Pada Ibu Bersalin

di RS. Betha Medika Sukabumi Tahun 2016

\begin{tabular}{ccc}
\hline Umur & Frekuensi & $\%$ \\
\hline Tidak Bekerja & 58 & 39,2 \\
Bekerja & 90 & 60,8 \\
\hline Jumlah & 148 & 100 \\
\hline
\end{tabular}


Tabel 5.5

Distribusi Frekuensi Kehamilan Ganda Pada Ibu Bersalin

di RS. Betha Medika Sukabumi Tahun 2016

\begin{tabular}{ccc}
\hline Umur & Frekuensi & $\%$ \\
\hline Tidak Gemelli & 141 & 95,3 \\
Gemelli & 7 & 4,7 \\
\hline Jumlah & 148 & 100 \\
\hline
\end{tabular}

2. Analisis Bivariat

Tabel 5.6

Pengaruh Umur terhadap Kejadian Ketuban Pecah Dini (KPD)

Pada Ibu Bersalin di RS. Betha Medika Sukabumi Tahun 2016

\begin{tabular}{|c|c|c|c|c|c|c|c|c|}
\hline tipara & & & & & & & & \\
\cline { 1 - 5 } Total & $\mathbf{7}$ & $\mathbf{1 0}$ & $\mathbf{7}$ & $\mathbf{1 0}$ & $\mathbf{1 4}$ & $\mathbf{1 0}$ & & \\
& $\mathbf{4}$ & $\mathbf{0}$ & $\mathbf{4}$ & $\mathbf{0}$ & $\mathbf{8}$ & $\mathbf{0}$ & & \\
\hline
\end{tabular}

Tabel 5.8

Pengaruh Status Pekerjaan terhadap Kejadian Ketuban Pecah Dini (KPD) Pada Ibu Bersalin di RS. Betha Medika Sukabumi Tahun 2016

\begin{tabular}{|c|c|c|c|c|c|c|c|c|c|c|c|c|c|c|c|c|c|}
\hline \multirow{2}{*}{\multicolumn{8}{|c|}{$\begin{array}{l}\text { Pada Ibu Bersalin di RS. Betha Medika } \\
\text { Sukabumi Tahun } 2016\end{array}$}} & \multirow{2}{*}{\multicolumn{2}{|c|}{$\begin{array}{l}\text { Status } \\
\text { Pekerja }\end{array}$}} & & \multirow{2}{*}{\multicolumn{2}{|c|}{ Total }} & & \\
\hline & & & & & & & & & & \multirow{2}{*}{\multicolumn{2}{|c|}{$\begin{array}{c}\text { Kont } \\
\text { rol }\end{array}$}} & \multirow{2}{*}{\multicolumn{2}{|c|}{$\begin{array}{c}\text { Kas } \\
\text { us }\end{array}$}} & & & & \\
\hline \multirow{3}{*}{$\begin{array}{l}\text { Umu } \\
\text { r lbu } \\
\text { Bers } \\
\text { alin }\end{array}$} & \multicolumn{4}{|c|}{$\begin{array}{c}\text { Ketuban Pecah } \\
\text { Dini (KPD) }\end{array}$} & & \multirow{2}{*}{$\begin{array}{c}\text { Nilai } \\
\text { P } \\
\text { Valu } \\
\text { e }\end{array}$} & \multirow{2}{*}{$\begin{array}{r}\text { OR } \\
\text { (95\% } \\
\text { cl) }\end{array}$} & & & & & & & & u & \\
\hline & \multicolumn{2}{|c|}{$\begin{array}{c}\text { Kontro } \\
\text { I }\end{array}$} & \multicolumn{2}{|c|}{ Kasus } & \multicolumn{2}{|c|}{ Total } & & & $\mathbf{a}$ & $\mathbf{n}$ & $\%$ & $\mathbf{N}$ & $\%$ & $n$ & $\%$ & & \multirow{6}{*}{$\begin{array}{c}2,8 \\
(1,4 \\
3- \\
5,6 \\
6)\end{array}$} \\
\hline & $\mathbf{N}$ & $\%$ & $\mathbf{N}$ & $\%$ & $n$ & $\%$ & \multirow{4}{*}{$\begin{array}{c}0,00 \\
3\end{array}$} & \multirow{2}{*}{\multicolumn{2}{|c|}{$\begin{array}{l}\text { Tidak } \\
\text { Bekerja }\end{array}$}} & & 5 & & 2 & & 3 & & \\
\hline $\begin{array}{c}\text { Tida } \\
\mathrm{k} \\
\text { Beris }\end{array}$ & $\begin{array}{l}3 \\
2\end{array}$ & $\begin{array}{l}4 \\
3,\end{array}$ & $\begin{array}{l}1 \\
4\end{array}$ & $\begin{array}{l}1 \\
8\end{array}$ & 46 & $\begin{array}{c}31 \\
1\end{array}$ & & & & $\begin{array}{l}3 \\
8\end{array}$ & $\begin{array}{l}1, \\
4\end{array}$ & $\begin{array}{l}2 \\
0\end{array}$ & $\begin{array}{l}7 \\
\text { ' } \\
0\end{array}$ & $\begin{array}{l}5 \\
8\end{array}$ & $\begin{array}{l}9, \\
2\end{array}$ & & \\
\hline iko & & 2 & & 9 & & & & $\begin{aligned} 1, \sqrt{55} \\
65\end{aligned}$ & & & 4 & & 7 & & 6 & 0 & \\
\hline $\begin{array}{c}\text { Beris } \\
\text { iko }\end{array}$ & $\begin{array}{l}4 \\
2\end{array}$ & $\begin{array}{l}5 \\
6, \\
8\end{array}$ & $\begin{array}{l}6 \\
0\end{array}$ & $\begin{array}{l}8 \\
1, \\
1\end{array}$ & 102 & $\begin{array}{c}68, \\
9\end{array}$ & & & Bekerja & $\begin{array}{l}3 \\
6\end{array}$ & $\begin{array}{l}8 \\
6\end{array}$ & $\begin{array}{l}5 \\
4\end{array}$ & , & $\begin{array}{l}9 \\
0\end{array}$ & $\begin{array}{l}0, \\
8\end{array}$ & $\begin{array}{l}0 \\
4\end{array}$ & \\
\hline $\begin{array}{c}\text { Tota } \\
\text { I }\end{array}$ & $\begin{array}{l}7 \\
4\end{array}$ & $\begin{array}{l}1 \\
0 \\
0\end{array}$ & $\begin{array}{l}7 \\
4\end{array}$ & $\begin{array}{l}1 \\
0 \\
0\end{array}$ & 148 & 100 & & & Total & $\begin{array}{l}7 \\
4\end{array}$ & $\begin{array}{l}1 \\
0 \\
0\end{array}$ & $\begin{array}{l}7 \\
4\end{array}$ & $\begin{array}{l}1 \\
0 \\
0\end{array}$ & $\begin{array}{l}1 \\
4 \\
8\end{array}$ & $\begin{array}{l}1 \\
0 \\
0\end{array}$ & & \\
\hline
\end{tabular}

Tabel 5.7

Pengaruh Paritas terhadap Kejadian Ketuban Pecah Dini (KPD)

Pada Ibu Bersalin di RS. Betha Medika Sukabumi Tahun 2016
Tabel 5.9

Pengaruh Kehamilan Ganda terhadap Kejadian Ketuban Pecah Dini (KPD) Pada Ibu Bersalin di RS. Betha Medika Sukabumi Tahun 2016

\begin{tabular}{|c|c|c|c|c|c|c|c|c|c|c|c|c|c|c|c|}
\hline \multirow{3}{*}{$\begin{array}{l}\text { Jumlah } \\
\text { Paritas }\end{array}$} & \multicolumn{4}{|c|}{$\begin{array}{c}\text { Ketuban Pecah } \\
\text { Dini (KPD) }\end{array}$} & \multirow{2}{*}{\multicolumn{2}{|c|}{ Total }} & \multirow{3}{*}{$\begin{array}{l}\text { Nil } \\
\text { ai P } \\
\text { Val } \\
\text { ue }\end{array}$} & \multirow{4}{*}{$\begin{array}{l}\text { Kehami } \\
\text { ORlan } \\
\text { (95\%nda } \\
\text { Cl) }\end{array}$} & \multicolumn{4}{|c|}{$\begin{array}{l}\text { Ketuban } \\
\text { Pecah Dini } \\
\text { (KPD) }\end{array}$} & \multirow{3}{*}{\multicolumn{2}{|c|}{ Total }} & \multirow{3}{*}{$\begin{array}{l}\text { Nil } \\
\text { ai P } \\
\text { Val } \\
\text { ue }\end{array}$} \\
\hline & \multicolumn{2}{|c|}{$\begin{array}{c}\text { Kontr } \\
\text { ol }\end{array}$} & \multicolumn{2}{|c|}{ Kasus } & & & & & \multirow{2}{*}{\multicolumn{2}{|c|}{$\begin{array}{c}\text { kontro } \\
I\end{array}$}} & \multirow{2}{*}{\multicolumn{2}{|c|}{$\begin{array}{c}\text { Kasu } \\
\mathrm{s}\end{array}$}} & & & \\
\hline & $\mathbf{N}$ & $\%$ & $\mathbf{N}$ & $\%$ & $n$ & $\%$ & & & & & & & & & \\
\hline \multirow[b]{2}{*}{ Primipara } & 3 & 47 & 1 & 20 & & 33 & \multirow{4}{*}{$\begin{array}{l}0,0 \\
01\end{array}$} & & $\mathrm{n}$ & $\%$ & $\mathbf{N}$ & $\%$ & $n$ & $\%$ & \multirow[t]{4}{*}{1,0} \\
\hline & 5 & ,3 & 5 & ,3 & 50 & ,8 & & 3,\$idak & 7 & 9 & 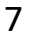 & 9 & 1 & 95 & \\
\hline \multirow{2}{*}{$\begin{array}{c}\text { Multipara } \\
\text { dan } \\
\text { Grandemul }\end{array}$} & 3 & 52 & 5 & 79 & \multirow{2}{*}{98} & 66 & & $\begin{array}{l}1 \text { 1,Qmelli } \\
7,30)\end{array}$ & 1 & $\begin{array}{l}5, \\
9 \\
\end{array}$ & 0 & $\begin{array}{l}4, \\
6 \\
\end{array}$ & $\begin{array}{l}4 \\
1 \\
\end{array}$ & 3 & \\
\hline & 9 & ,7 & 9 & ,7 & & ,2 & & Gemelli & 3 & 4, & 4 & 5, & 7 & 4,7 & \\
\hline
\end{tabular}




\begin{tabular}{|l|l|l|l|l|l|l|l|}
\hline & & 1 & & 4 & & \\
\hline Total & 7 & 1 & 7 & 1 & 1 & 100 & \\
& 4 & 0 & 4 & 0 & 4 & & \\
& & 0 & & 0 & 8 & & \\
\hline
\end{tabular}

\section{Pembahasan}

a. Kejadian Ketuban Pecah Dini (KPD)

Pada Ibu Bersalin di RS. Betha Medika

\section{Tahun 2016}

Hasil analisis data menunjukkan bahwa kejadian KPD di RS. Betha Medika Sukabumi Tahun 2016 memiliki jumlah yang merata sebanyak $50 \%$ ibu bersalin mengalami KPD dan 50\% tidak mengalami KPD.

Sampai saat ini penyebab ketuban pecah dini (KPD) belum diketahui secara pasti,namun kemungkinan yang menjadi faktor predisposisi adalah infeksi yang terjadi secara langsung pada selaput ketuban ataupun asenderen dari vagina atau serviks. Selain itu fisiologi selaput ketuban yang abnormal,serviks inkompetensia, kelainan letak janin,usia wanita kurang dari 20 tahun dan diatas 35 tahun,faktor golongan darah, merokok,keadaan social ekonomi, perdarahan antepartum,riwayat abortus dan persalinan preterm sebelumnya,riwayat KPD sebelumnya, defisiensi gizi yaitu tembaga atau asam askorbat, ketegangan Rahim yang berlebihan, kesempitan panggul, kelelahan ibu dalam bekerja, serta trauma yang didapat misalnya hubungan seksual, pemeriksaan dalam, amniosintesis dan paritas (Tahir,2010).

Kejadian Ketuban Pecah Dini (KPD) di RS. Betha Medika ditangani dengan cepat dan tepat karena untuk mencegah infeksi serta kematian ibu dan janin.

b. Pengaruh Umur terhadap Kejadian Ketuban Pecah Dini (KPD) pada Ibu Bersalin di RS. Betha Medika Tahun 2016

Hasil analisis data menunjukkan bahwa sebagian besar kelompok umur ibu bersalin berisiko di RS. Betha Medika Sukabumi Tahun 2016 yaitu sebanyak 68,9\% sedangkan kelompok umur ibu bersalin yang tidak berisiko yaitu sebanyak $31,1 \%$.

Berdasarkan hasil statistik terlihat bahwa ibu yang berumur berisiko mempunyai persentase mengalami kejadian KPD lebih tinggi yaitu $81,1 \%$ dibandingkan ibu yang berumur tidak berisiko hanya sebesar $18,9 \%$. Hasil uji statistik diperoleh $p$ value $=0,003$ artinya secara statistik ada pengaruh yang signifikan antara umur ibu dengan kejadian KPD. Hasil analisis diperoleh $\mathrm{OR}=3,3$ artinya ibu yang berumur berisiko mempunyai resiko mengalami KPD sebesar 3,3 kali lebih tinggi dibandingkan ibu yang berumur tidak berisiko. 
Hasil penelitian Ruth Canaya $\mathrm{Br}$ Sihotang, dkk. menunjukkan bahwa dari 388 responden ibu bersalin dengan kategori berisiko sebagian besar terjadi ketuban pecah dini sejumlah 140 orang (70,7\%). Dan hasil statistiknya menunjukkan bahwa ada hubungan antara umur dengan kejadian ketuban pecah dini di RSUD Ambarawa Tahun 2013 dengan pvalue $=0,000$.

Manuaba 2010 juga berpendapat bahwa umur merupakan salah satu faktor yang berhubungan dengan kualitas kehamilan.

\section{b. Pengaruh Paritas terhadap kejadian Ketuban Pecah Dini (KPD) pada Ibu Bersalin di RS. Betha Medika Tahun 2016}

Hasil analisis data menunjukkan bahwa sebagian besar kelompok jumlah paritas pada ibu bersalin multipara dan grandemultipara yang mengalami kejadian Ketuban Pecah Dini (KPD) di RS. Betha Medika Sukabumi Tahun 2016 yaitu sebanyak $66,2 \%$ sedangkan kelompok jumlah paritas pada ibu bersalin primipara yaitu sebanyak $33,8 \%$.

Berdasarkan hasil statistik terlihat bahwa ibu dengan multipara dan grandemultipara mempunyai persentase mengalami kejadian KPD lebih tinggi yaitu 79,7\% dibandingkan ibu dengan primipara hanya sebesar $33,8 \%$. Hasil uji statistik diperoleh $p$ value $=0,001$ artinya secara statistik ada pengaruh yang signifikan antara paritas dengan kejadian KPD. Hasil analisis diperoleh $\mathrm{OR}=3,5$ artinya ibu dengan paritas multipara dan grandemultipara mempunyai resiko mengalami KPD sebesar 3,5 kali lebih tinggi dibandingkan ibu dengan paritas primipara.

Hasil penelitian yang dilakukan oleh Siti Aisyah bahwa sebagian besar (65 \%) responden pada ibu bersalin primipara tidak mengalami kejadian ketuban pecah dini (KPD). menunjukkan bahwa kejadian ketuban pecah dini pada ibu bersalin primipara angka kejadiannya hanya sedikit.

Hal tersebut sesuai dengan hasil yang didapat oleh peneliti dikarenakan Ibu bersalin primipara belum pernah mengalami trauma akibat riwayat persalinan yang lalu sehingga tidak terjadi inkompetensia serviks suatu kondisi dimana mulut rahim mengalami pembukaan dan penipisan sehingga tidak bisa menahan janin dan selaput ketuban. Ibu yang baru pertama kali hamil dan sangat mengharapkan kehadiran seorang anak dalam pernikahannya dia akan sangat menjaga kehamilannya agar selalu sehat.

Sedangkan yang multipara dan grandemultipara disebabkan karena secara anatomi sebagian besar kondisi serviks ibu bersalin multipara memang sudah 
membuka akibat proses persalinannya yang lalu sehingga tidak bisa menahan dan melindungi selaput ketuban baik terhadap trauma maupun terhadap infeksi, seiring dengan tuanya kehamilan selaput ketuban akan mengalami pematangan dan penipisan, keadaan ini akan menyebabkan selaput ketuban mudah pecah. Disamping itu jika usia kehamilan sudah mendekati aterm ibu hamil sering mengalami kontraksi uterus atau yang disebut his pengiring, dalam hal ini ibu bersalin multipara yang kondisi serviks nya sudah membuka akan lebih mudah terjadi ketuban pecah dini dibandingkan dengan ibu bersalin primipara yang kondisi serviksnya masih menutup.

\section{c. Pengaruh Status Pekerjaan terhadap kejadian Ketuban Pecah Dini (KPD) pada Ibu Bersalin di RS. Betha Medika}

\section{Tahun 2016}

Hasil analisis data menunjukkan bahwa sebagian besar kelompok status pekerjaan pada ibu bersalin yang bekerja di RS. Betha Medika Sukabumi Tahun 2016 yaitu sebanyak 60,8\% sedangkan kelompok status pekerjaan pada ibu bersalin yang tidak bekerja yaitu sebanyak $39,2 \%$.

Berdasarkan hasil statistik terlihat bahwa ibu yang bekerja mempunyai persentase mengalami kejadian KPD lebih tinggi yaitu $60,8 \%$ dibandingkan ibu yang tidak bekerja hanya sebesar $39,2 \%$. Hasil uji statistik diperoleh $\mathrm{p}$ value $=0,004$ artinya secara statistic ada pengaruh yang signifikan antara status pekerjaan ibu dengan kejadian KPD. Hasil analisis diperoleh $\mathrm{OR}=2,8$ artinya ibu yang bekerja mempunyai resiko mengalami KPD sebesar 2,8 kali lebih tinggi dibandingkan dengan ibu yang tidak bekerja.

Menurut penelitian yang dilakukan oleh Suriani Tahir,dkk. Ibu yang mengalami KPD proporsinya lebih besar pada ibu yang kerja fisiknya menyebabkan kelelahan dan lama kerja >3 jam/hari yaitu 104 orang $(81,9 \%)$ dibandingkan dengan ibu yang kerja fisiknya tidak menyebabkan kelelahan dan lama kerja maksimal 3 jam/hari yaitu 23 orang $(18,1 \%)$.Hasil uji statistik menunjukkan nilai Odds Ratio (OR) = 3,6 tingkat kepercayaan (Cl) 95\% yaitu $2,16-6,06$. Oleh karena nilai LL dan UL tidak mencakup nilai 1 , maka ibu yang memiliki pekerjaan merupakan faktor risiko terhadap KPD, dimana risiko KPD pada ibu yang pekerjaannya berisiko tinggi adalah 3,6 kali lebih besar dibandingkan ibu yang berisiko rendah pada pekerjaannya.

Pola pekerjaan ibu hamil berpengaruh terhadap kebutuhan energi. Kerja fisik pada saat hamil yang terlalu berat dan dengan lama kerja melebihi tiga jam perhari dapat berakibat kelelahan. Kelelahan dalam bekerja menyebabkan lemahnya korion amnion sehingga timbul 
ketuban pecah dini. Pekerjaan merupakan suatu yang penting dalam kehidupan, namun pada masa kehamilan pekerjaan yang berat dan dapat membahayakan kehamilannya hendaklah dihindari untuk menjaga keselamatan ibu maupun janin (Notoatmodjo. 2003).

\section{d. Pengaruh Kehamilan Ganda terhadap} kejadian Ketuban Pecah Dini (KPD) pada Ibu Bersalin di RS. Betha Medika

\section{Tahun 2016}

Hasil analisis data menunjukkan bahwa sebagian besar kelompok kehamilan ganda pada ibu bersalin tidak gemelli di RS. Betha Medika Sukabumi Tahun 2016 yaitu sebanyak 95,3\% sedangkan kelompok kehamilan ganda pada ibu bersalin gemelli yaitu sebanyak $4,7 \%$.

Berdasarkan tabel 5.9 terlihat bahwa ibu yang tidak gemelli mempunyai persentase mengalami kejadian KPD lebih tinggi yaitu 94,6\% dibandingkan ibu yang gemelli hanya sebesar 5,4\%. Hasil uji statistik diperoleh $p$ value $=1,0$ artinya secara statistik tidak ada pengaruh yang signifikan antara kehamilan ganda dengan kejadian KPD.

Teori mengatakan bahwa hamil ganda dapat memungkinkan ketegangan rahim meningkat, sehingga membuat selaput ketuban pecah sebelum waktunya (Maria, 2007). Hal tersebut tidak sesuai dengan hasil penelitian yang didapat karena jumlah kasus yang lebih sedikit, dan dari alat teknologi juga sudah semakin maju sehingga kehamilan ganda dapat terdeteksi dari awal dan ibu bisa lebih mempersiapkan kehamilan nya secara maksimal.

\section{SIMPULAN}

\section{Simpulan}

Berdasarkan penelitian tentang “ Faktor-faktor yang Mempengaruhi Kejadian Ketuban Pecah Dini (KPD) pada Ibu Bersalin di RS.Betha Medika Sukabumi Tahun 2016", dapat disimpulkan bahwa :

1. Sebagian besar kelompok umur ibu bersalin sebanyak $68,9 \%$ sedangkan kelompok umur ibu bersalin yang tidak berisiko yaitu sebanyak $31,1 \%$. Ibu yang berumur berisiko mempunyai persentase mengalami kejadian KPD lebih tinggi yaitu $81,1 \%$ dibandingkan ibu yang berumur tidak berisiko hanya sebesar 18,9\%. Hasil uji statistik diperoleh $p$ value $=0,003$ artinya secara statistik ada pengaruh yang signifikan antara umur ibu dengan kejadian KPD. Hasil analisis diperoleh $\mathrm{OR}=3,3$ artinya ibu yang berumur berisiko mempunyai resiko mengalami KPD sebesar 3,3 kali lebih tinggi dibandingkan ibu yang berumur tidak berisiko. 
2. Sebagian besar kelompok jumlah paritas multipara dan grandemultipara yang mengalami kejadian Ketuban Pecah Dini (KPD) yaitu sebanyak 66,2\% sedangkan kelompok jumlah paritas pada ibu bersalin primipara yaitu sebanyak $33,8 \%$. Ibu dengan multipara dan grandemultipara mempunyai persentase mengalami kejadian KPD lebih tinggi yaitu $79,7 \%$ dibandingkan ibu dengan primipara hanya sebesar $33,8 \%$. Hasil uji statistik diperoleh $p$ value $=0,001$ artinya secara statistik ada pengaruh yang signifikan antara paritas dengan kejadian KPD. Hasil analisis diperoleh $\mathrm{OR}=3,5$ artinya ibu dengan paritas multipara dan grandemultipara mempunyai resiko mengalami KPD sebesar 3,5 kali lebih tinggi dibandingkan ibu dengan paritas primipara.

3. Sebagian besar kelompok status pekerjaan pada ibu bersalin yang bekerja yaitu sebanyak 60,8\% sedangkan kelompok status pekerjaan pada ibu bersalin yang tidak bekerja yaitu sebanyak $39,2 \%$. Ibu yang bekerja mempunyai persentase mengalami kejadian KPD lebih tinggi yaitu 60,8\% dibandingkan ibu yang tidak bekerja hanya sebesar $39,2 \%$. Hasil uji statistik diperoleh $p$ value $=0,004$ artinya secara statistic ada pengaruh yang signifikan antara status pekerjaan ibu dengan kejadian KPD. Hasil analisis diperoleh $\mathrm{OR}=2,8$ artinya ibu yang bekerja mempunyai resiko mengalami KPD sebesar 2,8 kali lebih tinggi dibandingkan dengan ibu yang tidak bekerja.

4. Sebagian besar kelompok kehamilan ganda pada ibu bersalin tidak gemelli yaitu sebanyak 95,3\% sedangkan kelompok kehamilan ganda pada ibu bersalin gemelli yaitu sebanyak $4,7 \%$. Ibu yang tidak gemelli mempunyai persentase mengalami kejadian KPD lebih tinggi yaitu 94,6\% dibandingkan ibu yang gemelli hanya sebesar $5,4 \%$. Hasil uji statistik diperoleh $\mathrm{p}$ value $=$ 1,0 artinya secara statistik tidak ada pengaruh yang signifikan antara kehamilan ganda dengan kejadian KPD.

\section{DAFTAR PUSTAKA}

Alimul Hidayat A. Aziz. 2007. Metode Penelitian Kebidanan \& Teknik Analisis Data. Salemba Medika, Jakarta

Alimul A Hidayat. Metode Penelitian Kebidanan Teknik Analisa Data. Jakarta ; Salemba Medika. 2009

Arikunto 2010. Prosedur Penelitian suatu Pendekatan Praktek. Jakarta ; Rineka Cipta 
Bagian Obstetri dan Ginekologi Fakultas Kedokteran UNPAD 1984. Obstetri Fisiologi. Elstar Offset : Bandung

Cunningham FG, et al, "Common Complications of Pregnancy" Williams Obstetrics, $21^{\text {st }}$ ed, Prentic Hall International Inc. Appleton and Lange, Connecticut 2001.

Cunningham Gary F. 2006. Obstetri Williams Edisi 21. EGC, Jakarta

Data Register Kebidanan Rumah Sakit Betha Medika. 2017. Sukabumi: Rumah Sakit Betha Medika Sukabumi

Depkes RI. 2008. Asuhan Persalinan Normal: Jakarta. JNPK-KR

Hastono, S. P. 2014. Statistik Kesehatan. Jakarta: Rajawali Pers.

Hidayat, A. Metode Penelitian Kebidanan Teknik Analisa Data. Jakarta : Salemba Medika. 2007

KepMenkes No.97, 2015. Kesehatan dalam Kerangka Sustainable Development Goals (SDGs), Jakarta : RAKORPOP Kementrian Kesehatan RI

Manuaba, I.B.G, dkk. . 2008. Gawat Darurat Obstetri Ginekologi \& Obstetri Ginekologi Sosial Untuk profesi Bidan. Jakarta : EGC

Notoatmodjo, Soekidjo. 2010. Metodologi Penelitian Kesehatan. Jakarta : Rineka Cipta.
Prawirohadjo, Sarwono.2010. IImu Kebidanan. Jakarta : Bina Pustaka

Prawirohardjo S. 2008.Buku Acuan Nasional Pelayanan Kesehatan Maternal dan Neonatal. Jakarta : YBP-SP

Rustam Mochtar, Prof., Dr., MPH, "Air Ketuban" Sinopsis Obstetri, Jilid I, Edisi I, EGC, Jakarta 1998

Saifuddin AB. 2010. Buku Panduan Praktis Pelayanan Kesehatan Maternal dan Neonatal. YBP-SP, Jakarta

Sayifuddin, Abdul Bari.dkk. 2001. Pelayanan Kesehatan Maternal dan Neonatal. Jakarta.JNPKKR-POGI

Sugiyono. Statistik untuk Penelitian. Bandung : CV Alfabeta. 2007

Sugiyono. Statistic untuk Pebelitian. Bandung : CV Alfabeta. 2005.

Varney Helen, dkk. 2006. Asuhan Kebidanan Edisi 4 Vol I, Jakarta-EGC Varney Helen, dkk. 2008. Buku Ajar Asuhan Kebidanan Volume 2. EGC, Jakarta Wiknjosastro, $\mathrm{H}, .2007$. Ilmu kebidanan. Jakarta: Yayasan Bina Pustaka Sarwono Prawihardjo.

Wiknjosastro Hanifa. 2006. IImu Kebidanan. YBP-SP, Jakarta

Ayah Bunda. 2011. Ketuban pecah dini. http//www.ayahbunda.co.id/artikel/ kehamilan/tips/mengatasi ketuban pecah dini. ( 07-02-2017) 
Jurnal Bidang Ilmu Kesehatan

Depkes RI. Angka Kematian Ibu dan Bayi

2010. http//:www.dinkes-ri.com.

(13-02-2017)
Hidayat, Asri, dkk. 2009. Asuhan Patologi Kebidanan. Jogjakarta : Nuha Medika Ketuban pecah dini. 